\title{
Hepatoprotective Effects of Sinapic Acid in the Streptozotocin-Induced Diabetic Rats
}

\section{Streptozotosin ile Indüklenen Diyabetik Sıçanlarda Sinapik Asidin Hepatoprotektif Etkileri}

\author{
Fikret Altindag \\ Department of Histology and Embryology, Faculty of Medicine, Van Yüzüncü Yul University, Van, Turkey
}

\begin{abstract}
Aim: Hepatotoxicity is one of the most important secondary complications of diabetes. The leading causes of diabetes-induced liver damage are oxidative stress and inflammation. Sinapic acid (SA) has been proposed as a potent antioxidant and antiinflamatuar. In the present study, we aimed to investigate the hepatoprotective effects of SA by evaluating TNF- $\alpha$, AST, ALT levels, and histological changes in the experimental diabetes model.
\end{abstract}

Material and Method: Rats were divided into four groups $(n=7)$ : Sham (S), SA, Diabetic (D), Diabetic+Sinapic Acid ( $D+S A)$. S group was given only saline by intragastric (i.g.). $S A$ group was received $20 \mathrm{mg} / \mathrm{kg} /$ day $S A$ by i.g. for 28 days. $D$ group was injected with a single dose of $50 \mathrm{mg} / \mathrm{kg}$ streptozotocin (STZ) intraperitoneal (i.p.). $D+S A$ was injected with a single dose of $50 \mathrm{mg} / \mathrm{kg}$ STZ i.p. and received $20 \mathrm{mg} / \mathrm{kg} /$ day $S A$ by i.g. for 28 days. Tumor necrosis factor-alpha (TNF- $\alpha$ ) expression was measured using the immunohistochemical method to assess inflammation in the liver. The liver was stained with Masson's trichrome (MT) stain to evaluate possible fibrosis in the liver and hematoxylin-eosin (H-E) stain for histological examination. In addition, serum aspartate aminotransferase (AST) and alanine transaminase (ALT) levels, which is liver function tests, were measured.

Results: $S$ and SA groups had normal histological architecture and negative TNF- $\alpha$ immunoexpression. The $D$ group had higher AST and ALT levels and MT staining intensity than the $S$ group. In addition to severe TNF- $\alpha$ immunoexpression, histopathological changes such as vascular dilatation, apoptotic cells, and infiltration of inflammatory cells were observed in group D. TNF- $\alpha$ immunoexpression histopathological changes, AST and ALT levels decreased in the D+SA group compared to the $D$ group.

Conclusion: Our study revealed that SA might have a hepatoprotective effect against hepatotoxicity in STZ-induced diabetic rats.

Key words: diabetes; liver; rat; sinapic acid; TNF- $\alpha$

\section{ÖZET}

Amaç: Hepatotoksisite diyabetin en önemli sekonder komplikasyonlarından biridir. Diyabetin neden olduğu karaciğer hasarının ana nedenleri oksidatif stres ve inflamasyondur. Sinapik asidin güçlü bir antioksidan ve antiinflamatuar olduğu öne sürülmüștür. Bu çalıșmada, deneysel diyabet modelinde sinapik asidin (SA) hepatoprotektif etkilerini TNF- $\alpha$, AST, ALT seviyeleri, MT boyama yoğunluğu ve histolojik değișiklikleri değerlendirerek araștırmayı amaçladık.

Materyal ve Metot: Sıçanlar dört gruba ayrıldı ( $n=7)$ : Sham (S), SA, Diyabetik (D), Diyabetik+Sinapik Asit (D+SA). S grubuna intragastrik (i.g.) yolla serum fizyolojik verildi. $S A$ grubuna 28 gün boyunca i.g. yolla $20 \mathrm{mg} / \mathrm{kg} / \mathrm{gün} S A$ verildi. D grubuna tek doz $50 \mathrm{mg} / \mathrm{kg} S T Z$ intraperitoneal (i.p.) enjekte edildi. D+SA grubuna, tek doz $50 \mathrm{mg} / \mathrm{kg}$ STZ i.p. yolla enjekte edildi ve 28 gün boyunca 20 mg/kg/gün SA i.g. yolla verildi. Tümor nekroz faktör-alfa (TNF- $\alpha$ ) ekspresyonu immünohistokimyasal yöntemle değerlendirildi. Karaciğerde olası fibrozisi değerlendirmek için Masson's trichrome (MT) boyası ve histolojik inceleme için hematoksilen-eozin (H-E) boyası ile karaciğer boyandı. Ayrıca karaciğer fonksiyon testleri olan serum AST ve ALT seviyeleri ölçüldü.

Bulgular: S ve SA grupları normal histolojik mimariye ve negatif TNF-a immüno-ekspresyonuna sahipti. S grubu ile karșılaștırıldığında, $D$ grubu daha yüksek AST ve ALT seviyelerine ve MT boyama yoğunluğuna sahipti. $D$ grubunda șiddetli $T N F-\alpha$ immün ekpresyonunun yanı sıra vasküler dilatasyon, apoptotik hücreler ve inflamatuar hücrelerin infiltrasyonu gibi histopatolojik değișiklikler gözlendi. D grubu ile karșılaștırıldığında D+SA grubunda TNF- $\alpha$ immunoexpression, histopatolojik değișiklikler, AST ve ALT seviyeleri azaldı.

Sonuç: Çalıșmamız, STZ ile indüklenen diyabetik sıçanlarda SA'nın hepatotoksisiteye karșı hepatoprotektif bir etkiye sahip olabileceğini ortaya koydu.

Anahtar kelimeler: diyabet; karaciğer; sıçan; sinapik asit; TNF- $\alpha$

IIletișim/Contact: Fikret Altındă̆, Van Yüzüncü Yul University Faculty of Medicine, Department of Histology and Embryology, Van, Turkey • Tel:0505 5767940 • E-mail:fikretaltindag@yyu.edu.tr • Gelis/Received: 16.09.2021 • Kabul/Accepted: 09.12.2021

ORCID: Fikret Altındăg, 0000-0002-7085-623X 


\section{Introduction}

The liver is one vital organ in the body, which performs many vital functions such as detoxification, secretion, synthesis, and storage. Liver damage, fibrosis, and liver inflammation have occurred due to many pathologies such as diabetes and viral infections ${ }^{1}$. Concern regarding diabetes is that diabetes can cause severe symptoms that can affect multiple vital organ systems such as hepatotoxicity, nephrotoxicity, retinotoxicity, neurotoxicity and are difficult to reverse ${ }^{2}$. Diabetes is thought to be one of the most important causes of liver disease. Therefore, the prevalence of liver disease in diabetic patients is quite high ${ }^{3}$. Two critical parameters of diabetes-induced liver injury are inflammation and oxidative stress ${ }^{4}$. Increased inflammatory response and oxidative stress are caused by hepatocyte injury and its death ${ }^{2}$. Proinflammatory cytokines such as TNF- $\alpha$ play an essential role in the pathogenesis of diabetes ${ }^{5}$. Hyperglycemia active the release of pro-inflammatory cytokine TNF- $\alpha$ that is produced mainly in macrophages ${ }^{6}$.

Primary prevention and early treatment are necessary to avoid late diagnosis and advanced damage of diabetes. The growth and development of diabetic complications cause acute metabolic diseases such as obesity, insulin resistance, hyperglycemia, and hyperlipidemia ${ }^{7}$. Previous studies have reported that diabetes is associated with liver pathologies such as fibrosis, cirrhosis, increased liver function enzymes, and abnormal glycogen and fat accumulation in the liver ${ }^{1,8}$.

Since antidiabetic drugs cause undesirable side effects, it has been observed that the patient develops resistance after prolonged using?. New treatment strategies are needed due to the limited effectiveness of existing treatments caused by these chronic symptoms in the long run. Animal models have long played a critical role in the study and elucidation of disease pathophysiology, identifying target therapeutic molecules, and evaluating new therapeutic agents and treatments in vivo/in vitro. SA, found in various plants, has been reported to be an antihyperglycemic, antiinflamatuar, and antioxidant agent ${ }^{10-12}$. However, the mechanism of action of SA on the liver in diabetic animals is not fully understood. Therefore, we aimed to assess the possible protective effects of SA in the hepatotoxicity caused by STZ in diabetic rats by determining TNF- $\alpha$ expression, liver function tests, and structural changes in the liver.

\section{Materials and Methods}

\section{Drugs and Chemicals}

SA (Sigma CAS number: 530-59-6) was acquired from Sigma-Aldrich. STZ (sc-200719) and TNF- $\alpha$ primary antibody (sc-52746) was obtained from Santa Cruz Biotechnology (Dallas, TX, United States).

\section{Experimental Animals and Design}

The experiment protocol was approved by Van Yüzüncü Yil University Animal Experiments Local Ethics Committee (approval number: 2019/12), Van, Turkey. In our study, we used a total of 28 adult Wistar albino rats (200-250 g weighing and 2-3 months old) obtained from Van Yüzüncü Yil University Experimental Medicine Application and Research Center. The animals were allowed to live under standard conditions $\left(24 \pm 2^{\circ} \mathrm{C}, 12 \mathrm{~h}\right.$ light/dark cycle), and their water and foods were given as ad libitum. The animals were grouped into 7 in each group.

1. S group: The sham group was received saline for 28 days.

2. D group: All animals were injected $50 \mathrm{mg} / \mathrm{kg}$ with a single dose of STZ (i.p.) $)^{12,13}$.

3. SA group: All animals in this group were administered $20 \mathrm{mg} / \mathrm{kg}$ with a dose of SA for 28 days (i.g.) ${ }^{14}$.

4. D + SA group: All animals in this group were administered $20 \mathrm{mg} / \mathrm{kg}$ with a dose of SA (i.g.) after being administered STZ for 28 days.

\section{Collection of Samples}

The thoracic region was dissected, and blood taken from the heart was kept in heparinized tubes. The blood taken from the heart's left ventricle from the dissected thoracic region was transferred to heparinized tubes. For histological and immunohistochemical examination, liver tissue from rats was immersed in formalin solution for fixation.

\section{Measurements of Liver Function Markers}

Serums were obtained by centrifuging the blood samples at $3000 \mathrm{rpm}$ (10 min). Then, serum was collected to measure AST and ALT levels. The samples were analyzed to determine ALT and AST levels via an automated biochemical autoanalyzer (Abbott, Architect ci16200, USA). 


\section{Histological Analysis}

After fixation and routine tissue processing, the liver was embedded in paraffin. Liver sections taken from paraffin blocks with a thickness of $5 \mu \mathrm{m}$ were stained with H-E for histopathological evaluation of the liver and stained with M-T staining for possible liver fibrosis evaluation. Sections were examined by light microscopy (Olympus BX53, Japan). Stained sections were examined, an average of 10-15 areas were evaluated by random sampling for the liver of each animal in the groups. The findings were evaluated semi-quantitatively according to the degree of damage observed in the examined regions. Accordingly, it was evaluated as: normal tissue: -, very minor damage: + (damage $<25 \%)$, minor damage: ++ (25-50\%), medium damage: $+++(50-75 \%)$, severe damage: $++++($ damage $>75 \%)$.

\section{Immunohistochemical Analysis}

The streptavidin peroxidase method was used for immunohistochemical analysis. $5 \mu \mathrm{m}$ thick sections taken from paraffin blocks of the liver were deparaffinized and rehydrated and then incubated in 3\% Hydrogen peroxide $\left(\mathrm{H}_{2} \mathrm{O}_{2}\right)$, citrate buffer ( $\mathrm{ph}$ 6.1), Ultra V Block, TNF $\alpha$ antibody (Santa Cruz Biotechnology, dilution ratio: 1/100), Biotinylated Goat Anti-Polyvalent and Streptavidin-peroxidase conjugate, respectively. Sections were washed in distilled water and then incubated in Diaminobenzidine (DAB) as a chromogen and stained with Mayer's hematoxylin as a counterstain. Immune positive cells in the sections were counted and evaluated by $\mathrm{H}$-score.

\section{Statistical Analysis}

Statistical analyses were performed by using SPSS 21.0 software. The one-way analysis of variance (ANOVA) was used to determine the differences between the groups, followed by Tukey post hoc. $\mathrm{P} \leq 0.05$. All group data were expressed as mean \pm standard deviations (SD).

\section{Results}

\section{Effects of SA on levels of AST and ALT in diabetic rats}

We assessed liver function markers and found significant increases in AST and ALT levels in the D group compared to the $S$ group $(p<0.05)$. But AST and ALT significantly decreased in the $\mathrm{D}+\mathrm{SA}$ group compared to the $\mathrm{D}$ group $(p<0.05)$. There was no significant difference in the SA group compared to the control group (Table 1).

\section{Histological Observations of Liver Tissues With H-E and MT Stainings}

In histological examination with $\mathrm{H}-\mathrm{E}$ stain, $\mathrm{S}$ (Figure 1A) and SA (Figure 1D) groups had normal histological structure. Vascular dilatation, apoptotic cells, and infiltration of inflammatory cells were seen in the D group (Figure 1B). However, there were fewer apoptotic cells and infiltration in the D+SA group compared to the D group (Figure 1C).

In the light microscopic examination of the MT staining performed to evaluate fibrosis in the liver, dense fibrous tissue was found mainly around the vessel in group D (Figure 2B) compared to group $S$ (Figure 2A). However, SA treatment reduced fibrosis in diabetic rats (Figure 2C). MT staining of the SA group was similar to the $S$ group.

\section{Immunohistochemical Evaluation of TNF- $\alpha$ in the Liver}

To determine the effects of SA on inflammation in the hepatic tissue, we assessed the expressions of the TNF- $\alpha$ using the immunohistochemical method. S (Figure 3A) and SA (Figure 3D) groups were negative. It was found that the expressions of TNF- $\alpha$ increased in the $\mathrm{D}$ group and especially around the central vein (Figure 3B). But, SA treatment reduced TNF- $\alpha$ expression in the liver tissue of STZ-induced diabetic rats (Figure 3C). The TNF- $\alpha$ score is given in Figure 4.

Table 1. Effects of the treatments of SA on AST and ALT levels in diabetic rats

\begin{tabular}{lccc}
\hline & & \multicolumn{2}{c}{ Groups } \\
\cline { 2 - 4 } Parameters & C & D & D + SA \\
\hline AST activity (mIU/L) & $145,00 \pm 16,06^{\text {a }}$ & $459,71 \pm 91,72^{\text {b }}$ & $245,71 \pm 32,08^{\mathrm{a}, \mathrm{b}}$ \\
ALT activity (IU/L) & $48,57 \pm 4,38^{\text {a }}$ & $319,00 \pm 52,44^{\text {b }}$ & $184,57 \pm 15,15^{\mathrm{a}, \mathrm{b}}$ \\
\hline
\end{tabular}

Values are expressed as means \pm SD.

Significant differences as compared with the $D$ group at $P<0.05$.

$b$ Significant differences as compared with the $\mathrm{C}$ group at $\mathrm{P}<0.05$. 

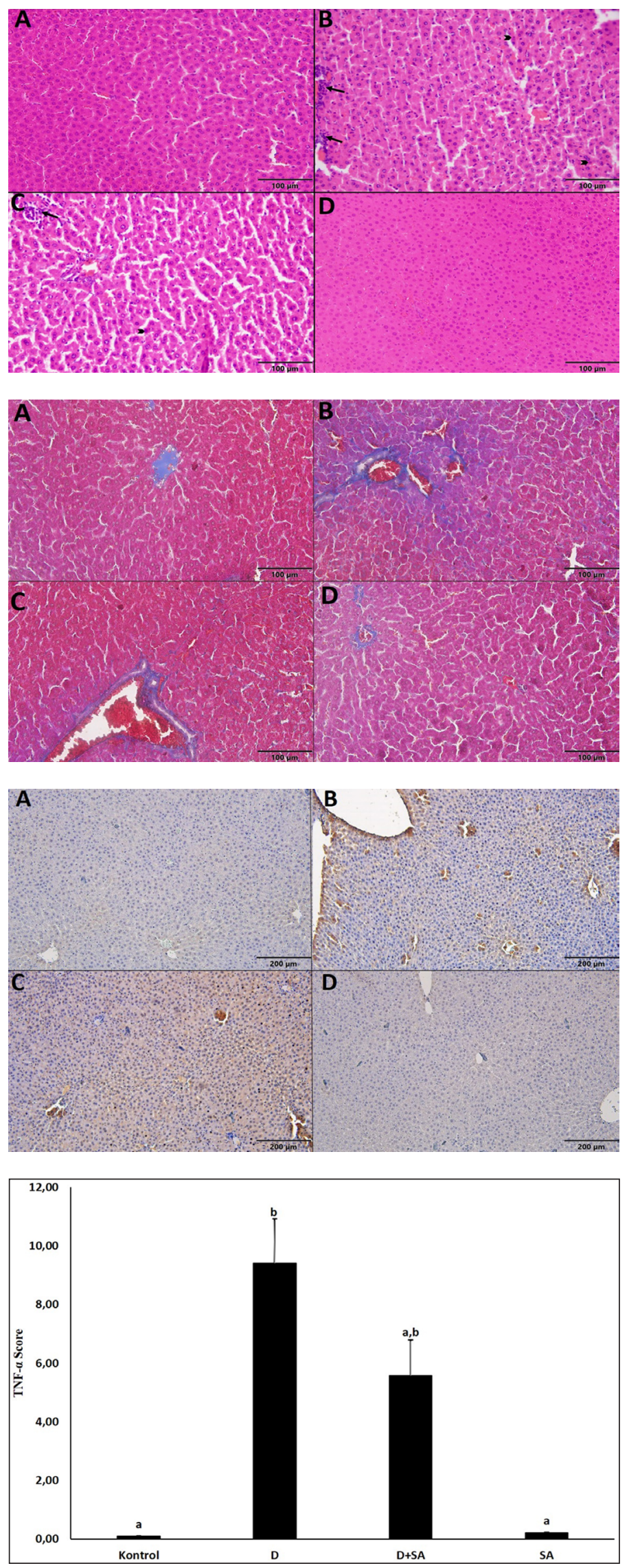

Figure 1. Light microscopic images of liver sections stained with $H-E$ staining $(x 40)$. The vessels were dilated in the $D$ group $(B)$ relative to the $S$ group $(\boldsymbol{A})$, and $D+S A$ treated groups $(\boldsymbol{C})$. Cell infiltration (arrow) and apoptotic cells (arrow head) are observed in group $D$. Less cell infiltration, and apoptotic cells are kept in the $D+S A$ group compared to the $D$ group $(\times 40)$.

Figure 2. Light microscopic images of liver sections stained with MT staining (x40). A, sham group; $B, D$ group; $C, D+S A$ group; $D, S A$ group. Collagen fibers are stained with blue. Group D has intense MT staining (B). $D+S A$ has moderate $M T$ (C).

Figure 3. Representative photomicrographs of immunohistochemical detection of TNF- $\alpha$ in the rat liver tissue $(\times 20)$. The liver sections of the $S(\boldsymbol{A})$ and $S A(D)$ groups are negative. The intense immunoexpression of TNF- $\alpha$ in $D$ group $(\boldsymbol{B})$ and low immunoexpression of TNF- $\alpha$ in $D+S A$ group (C) are present.

Figure 4. The immunohistochemical score of TNF- $\alpha$ expression. Intense $T N F-\alpha$ expression in group $D$ and moderate TNF- $\alpha$ expression in group $D+S A$ are observed. 


\section{Discussion}

Diabetes, characterized by hyperglycemia, occurs mainly due to impaired insulin synthesis and secretion $^{15}$. It has many harmful effects on the structure and function of many organs, especially the liver. Some antioxidants, including SA, naturally occur as protective and hypoglycemic agents ${ }^{16}$. This study aimed to investigate the possible hepatoprotective effects of SA against SZT-induced hepatotoxicity.

It has been reported that AST and ALT increased in STZ-induced diabetic animals. The increase in levels of these enzymes is an indication of disruption of hepatocyte membrane integrity ${ }^{17}$. Therefore, these enzymes are routinely used as serum enzyme markers in detecting liver diseases ${ }^{18}$. In our study, AST and ALT levels increased in the untreated diabetic group. But, SA treatment decreased AST and ALT levels in the D+SA group. Consistent with our study, Yang and Kang revealed that serum AST and ALT levels increased in STZ-induced diabetic rats. Still, quercetin and resveratrol treatment decreased the increased AST and ALT levels ${ }^{19}$. Elevated AST and ALT levels in serum are indicators of abnormal liver function resulting from their release into the bloodstream from liver-damaged cells. The present study reveals that SA can exert a hepatoprotective effect against STZinduced hepatotoxicity by reducing the level of liver function enzymes. Our findings are compatible with the literature ${ }^{20}$.

Histopathological examinations with light microscopy are used in pathophysiology to give the morphological structures of cells that can change when exposed to oxidative stress. Many studies have been found in the literature on hepatocyte replacement caused by metabolic diseases and therapeutic treatments ${ }^{21-24}$. In our study, changes such as apoptotic cells, enlargement of central vein, and sinusoids were observed in the light microscopic examination of the liver. But, SA treatment restored these pathological changes in liver histology. Consistent with the histopathological findings of our study, Ghara et al. reported that the liver of diabetic animals exhibits pathological changes such as an abnormal sinusoid and necrosis. Still, Capparis decidua extract reduced these pathological changes ${ }^{25}$. Similarly, Nambirajan et al. reported that the liver exhibited changes such as lipid accumulation, necrosis, and swelling of hepatocytes in diabetic rats treated with STZ. Still, the bud and flower of Avaram reduced these pathologies ${ }^{4}$.
Hepatocytes play an essential role in the metabolism of different nutrients, especially carbohydrates ${ }^{26}$. The lipid metabolism pathogenesis and high-level glucose play an important role in liver pathogenesis, including liver fibrosis ${ }^{27}$. It has been reported that TGF- $\beta$, which is accepted as an indicator of liver fibrosis, increases the expression of extracellular matrix genes and thus causes liver fibrosis by increasing the accumulation of type collagen fibrils ${ }^{1}$. In addition, MT staining was carried out to establish the fibrosis degree or accumulation of collagen. The STZ-induced rat liver tissue sections showed noticeable collagen accumulation. But, SA treatment showed a noteworthy reduction in fibrosis in STZ-induced rats. These findings revealed that SA plays a significant role in liver protection, as evident by low collagen accumulation in the SA treatment group. Our histopathological findings showed that SA reduced liver damage and dysfunction in diabetic rats.

The liver expresses receptors for many stimuli that stimulate inflammatory markers such as TNF- $\alpha$, which cause the activation of kupffer cells ${ }^{28}$. Inflammation is a pathological condition primarily associated with liver injury induced by diabetic complications ${ }^{29}$. Previous studies have reported the occurrence of liver inflammation in an experimental animal model of STZ-induced diabetes ${ }^{1}$. Wang et al. demonstrated that liver inflammation increased in diabetic rats, but Quercetin and Allopurinol reduced the increased liver inflammation ${ }^{30}$. Similarly, Chang et al. reported that liver inflammation increased in STZ-induced diabetic rats, and Resveratrol decreased the increased liver inflammation ${ }^{31}$. Consistent with the previous study ${ }^{1,30}$, according to the immunohistochemical findings of our study, the expression of TNF- $\alpha$, a marker of inflammation, increased in the liver of diabetic rats. In addition, histopathological findings revealed an increase in the infiltration of inflammatory cells in the liver sections of rats in the diabetic group. However, SA treatment decreased both TNF- $\alpha$ expression and cell infiltration in the liver. These findings of our study reveal that SA may have an anti-inflammatory effect in the liver of diabetic rats.

\section{Conclusion}

As a result, the findings of our study demonstrated that SA could have a hepatoprotective effect by reducing the increased inflammation, fibrosis and apoptotic cell 
number in diabetic rats induced by STZ. Therefore, although additional studies are needed to support our study's findings, it is suggested that SA can be used as a hepatoprotective agent in diabetic patients.

\section{Acknowledgments}

Any institution or organization did not support this study. The study was carried out with the laboratory facilities of Van Yüzüncü Yil University, Faculty of Medicine, Department of Histology and Embryology.

\section{References}

1. El-Naggar ME, Al-Joufi F, Anwar M, Attia MF, El-Bana MA. Curcumin-loaded PLA-PEG copolymer nanoparticles for treatment of liver inflammation in streptozotocininduced diabetic rats. Colloids and Surfaces B Biointerfaces 2019;177:389-398.

2. Mohamed J, Nazifah AHN, Zariyantey AH, Budin SB. Mechanisms of Diabetes-Induced Liver Damage. Sultan Qaboos Univ Med J 2016;16(2):132-141.

3. Tolman KG, Fonseca V, Dalpiaz A, Tan MH. The spectrum of liver disease in type 2 diabetes and management of patients with diabetes and liver disease, Diabetes Care 2007;30:734-743.

4. Nambirajan G, Karunanidhi K, Ganesan A, Rajendran R, Kandasamy R, Elangovan A, Thilagar S. Evaluation of antidiabetic activity of bud and flower of Avaram Senna (Cassia auriculata L.)In high-fat diet and streptozotocin-induced diabetic rats. Biomedicine \& Pharmacotherapy 2018;108:14951506.

5. Chandirasegaran G, Elanchezhiyan C, Ghosh K, Sethupathy S. Berberine chloride ameliorates oxidative stress, inflammation, and apoptosis in the pancreas of Streptozotocin induced diabetic rats. Biomedicine \& Pharmacotherapy 2017;95:175-185.

6. Ziamajidi N, Nasiri A, Abbasalipourkabir R, Moheb SS. Effects of garlic extract on TNF- $\alpha$ expression and oxidative stress status in the kidneys of rats with STZ + nicotinamide-induced diabetes. Pharmaceutical Biology 2017;55(1):526-531.

7. Jia Q, Yang R, Liu XF, Ma SF, Wang L. Genistein attenuates renal fibrosis in streptozotocin-induced diabetic rats. Mol Med Rep2019;19(1):423-431.

8. Guven A, Yavuz O, Cam M, Ercan F, Bukan N, Comunoglu C, Gokce F. Effects of melatonin on streptozotocin-induced diabetic liver injury in rats. Acta Histochem 2006;108:85-93.

9. Zych M, Wojnar W, Borymski S, Szałabska K, Bramora P, Kaczmarczyk-Sedlak I. Effect of rosmarinic acid and sinapic acid on oxidative stress parameters in the cardiac tissue and serum of type 2 diabetic female rats. Antioxidants 2019;8(12):579-579.

10. Kanchana G, Shyn WJ, Malini P, Rajadurai M. Effect of sinapic acid on antiperoxidative and antioxidant potential in normal and streptozotocin-induced diabetes in Wistar rats. Int J Pharm Clin Res 2011;3(1):5-9.
11. Alaofi AL, Ahmed Khan T, Criscuolo D, Ahmad Ansari M. Sinapic Acid Ameliorates the Progression of Streptozotocin (STZ)-Induced Diabetic Nephropathy in Rats via NRF2/ HO-1 Mediated Pathways 2020;11:1119.

12. Altındağ F, Rağbetli MÇ, Özdek U, Koyun N, Ismael Alhalboosi JK, Elasan S. Combined treatment of sinapic acid and ellagic acid attenuates hyperglycemia in streptozotocininduced diabetic rats. Food and Chemical Toxicology 2021;156:112443.

13. Uzar E, Alp H, Cevik MU, Fırat U, Evliyaoglu O, Tufek A, Altun Y. Ellagic acid attenuates oxidative stress on brain and sciatic nerve and improves histopathology of brain in streptozotocin-induced diabetic rats. Neurological Sciences 2012;33:567-574.

14. Shahmohamady P, Eidi A, Mortazavi P, Panahi N, MinaiTehrani D. Effect of sinapic acid on memory deficits and neuronal degeneration induced by intracerebroventricular administration of streptozotocin in rats. Polish Journal of Pathology 2018;69(3):266-266.

15. Lyoussi B, Bakour M, El Menyiy N, El Ghouizi A. Hypoglycemic, hypolipidemic and hepato-protective effect of bee bread in streptozotocin-induced diabetic rats. Avicenna Journal of Phytomedicine 2021;11(4):343-352.

16. Arya A, Al-Obaidi MMJ, Shahid, N, Noordin MIB, Looi CY, Wong WF, Khaing SL, Mustafa MR. Synergistic effect of quercetin and quinic acid by alleviating structural degeneration in the liver, kidney and pancreas tissues of STZ-induced diabetic rats: a mechanistic study. Food and Chemical Toxicology 2014;71:183-196.

17. Nithya R, Subramanian S. Antioxidant properties of sinapic acid: In vitro and in vivo approach. Asian Journal of Pharmaceutical and Clinical Research 2017;10(6):255-255.

18. Hussein J, El Naggar ME, LatifYA, Medhat D, El Bana M, Refaat E, Morsy S. Solvent-free and one pot synthesis of silver and zinc nanoparticles: Activity toward cell membrane component and insulin signaling pathway in experimental diabetes. Colloids Surf B Biointerfaces 2018;170:76-84.

19. Yang DK, Kang HS. Anti-Diabetic Effect of Cotreatment with Quercetin and Resveratrol in Streptozotocin-Induced Diabetic Rats. Biomol Ther 2018;26(2):130-138.

20. Pandi A, Kalappan VM. Pharmacological and therapeutic applications of Sinapic acid-an updated review. Molecular Biology Reports 2021;48:3733-3745.

21. Al-Baqami NM, Hamza RZ. Protective Effect of Resveratrol against Hepatotoxicity of Cadmium in Male Rats: Antioxidant and Histopathological Approaches. Coatings 2021;11:594-604.

22. Bento-Silva A, Koistinen VM, Mena P, Bronze MR, Hanhineva K, Sahlstrøm S, Kitrytė V, Moco S, Aura AM. Factors affecting intake, metabolism and health benefits of phenolic acids: do we understand individual variability? European Journal of Nutrition 2020:59(4):1275-1293. 
23. Raish M, Ahmad A, Ansari MA, Alkharfy KM, Ahad A, AlJenoobi FI, Al-Mohizea A M, Khan A, Ali N. Effects of sinapic acid on hepatic cytochrome P450 3A2, 2C11, and intestinal P-glycoprotein on the pharmacokinetics of oral carbamazepine in rats: Potential food/herb-drug interaction. Epilepsy Research 2019; 153:14-18.

24. Torbenson M, Washington K. Pathology of liver disease: advances in the last 50 years. Human Pathology 2020;95:7898.

25. Ghara AR, Ghadi FE, Hosseini SH, Piacente S, Cerulli A, Alizadeh A, Mirmahmoudi R. Antioxidant and Antidiabetic Effect of Capparis decidua Edgew (Forssk.)Extract on Liver and Pancreas of Streptozotocin-Induced Diabetic Rats. J Appl Biotechnol Rep 2021;8(1):76-82.

26. Bilal M, Iqbal MS, Shah SB, Rasheed T, Iqbal H. Diabetic complications and insight into antidiabetic potentialities of ethno-medicinal plants: a review. Recent Patents on Inflammation \& Allergy Drug Discovery 2018;12(1):7-23.

27. Chandrasekara A, Shahidi F. Herbal beverages: Bioactive compounds and their role in disease risk reduction-A review. Journal of Traditional and Complementary Medicine 2018;8(4):451-458.
28. Brea R, Motiño O, Francés D, García-Monzón C, Vargas J, Fernández-Velasco M, Boscá L, Casado M, Martín-Sanz P, Agra N. PGE2 induces apoptosis of hepatic stellate cells and attenuates liver fibrosis in mice by downregulating miR-23a$5 p$ and miR-28a-5p, Biochimica et Biophysica Acta (BBA)Molecular Basis of Disease 2018;1864:325-337.

29. Zhao Y, Chen SJ, Wang JC, Niu HX, Jia QQ, Chen XW, Du XY, Lu L, Huang B, Zhang Q, Chen Y, Long HB. Sesquiterpene Lactones Inhibit Advanced Oxidation Protein ProductInduced MCP-1 Expression in Podocytes via an IKK/NF- $\kappa$ BDependent Mechanism 2015;2015:934058.

30. Wang W, Wang C, Din, XQ, Pan Y, Gu TT, Wang MX, Liu YL, Wang FM, Wang, SJ, Kong LD. Quercetin and allopurinol reduce liver thioredoxin-interacting protein to alleviate inflammation and lipid accumulation in diabetic rats. British Journal of Pharmacology 2013;169(6):1352-1371.

31. Chang CC, Chang C Y, Huang JP, Hung LM. Effect of Resveratrol on Oxidative and Inflammatory Stress in Liver and Spleen of Streptozotocin-Induced Type 1 Diabetic Rats. Chinese Journal of Physiology 2012;55. 